\title{
PANEL WIDTH AFFECTED BY ROCK MASS CLASSIFICATIONS (ABU-TARTUR PHOSPHATE MINES)
}

\author{
M. A. Hussein", S.S. Imbaby, A. R. Ibrahim \\ Mining and Metallurgical Engineering Dept. Faculty of Engineering, Assiut University, Egypt
}

Received 30 January 2013 , accepted 19 February 2013

\begin{abstract}
Rock mass classification systems consider one of the design tools, which are used in conjunction with engineering assessments and other design approaches. There are many classification systems, which are widely employed in rock engineering. In this study one of these systems is used for the selection of the optimum panel width in phosphate mine AbuTartur area. Geological Strength Index (GSI) is one of these systems which enables for calculations of the panel width. Data for the GSI system are obtained from geological reports, some field measurements and laboratory tests. The obtained panel width (wall length) for Abu-Tartur area is calculated to be about $100 \mathrm{~m}(102 \mathrm{~m})$ which differs strongly from the applied length in the area $(150 \mathrm{~m})$. So, it is recommended to apply this obtained length to secure safe mining conditions without roof falls which is the main problem facing underground mining in this area.
\end{abstract}

Keywords: Rock Mass Classification - Geological Strength Index (GSI) - Abu-Tartur longwall phosphate mine- Panel width

\section{Introduction}

Rock mass property is governed by the properties of intact rock materials and of the discontinuities in the rock. The behaviour of the rock mass is also influenced by the conditions of the rock mass properties, in-situ stresses and groundwater pressures. The quality of a rock mass type can be quantified by means of rock mass classifications [1].

Most modern rock mass classification systems assess and rate the factors affecting the stability/instability of rock masses surrounding underground excavations and make support recommendations. It is for this reason that, for many years, rock mass classification systems have formed the basis of the design of mining methods, optimum excavation dimensions, and support requirements for shallow and deep mines [2].

There are many factors affecting the panel width such as geological conditions, rock mass properties, mining depth, ore properties, ore thickness, economical factors, type of extraction machines (cutter, loader cutter), ventilation conditions and type of supports. One of these factors is the rock mass properties needed for calculating the panel width which can be determined from rock mass classification systems; while in ancient years, panel width was determined mainly, by the type of extraction machines (cutter, loader cutter) and check it by ventilation conditions [3].

The aim of this research is to apply rock mass classification systems for the selection of the optimum panel width in longwall phosphate mine (Abu-Tartur area). One of these systems is GSI method proposed by Hoek and Brown [4, 5, 6] which determines

\footnotetext{
* Corresponding author.

Mining and Metallurgical Engineering Dept. Faculty of Engineering, Assiut University, Egypt
} 
M. A. Hussein et al., Panel width affected by rock mass classifications (abu-tartur phosphate mines), pp. 1364 - 1379

rock mass properties to calculate panel width. GSI values for roof rocks and phosphate ore are determined from geological conditions, as lithology, structure of the interlocking of rock blocks and the conditions of the surfaces between these blocks. Laboratory tests are carried out to determine uniaxial compressive strength for phosphate ore and roof rocks. In calculating the panel width Salmon and Munro formula is used to calculate pillar strength. Taking into consideration that the factor of safety equals to $1.3[7,8,9]$.

\section{Rock mass properties}

Estimates of the strength and deformation characteristics of rock mass are required for almost any form of analysis used for the design of slopes, foundations and design of underground excavations. Hoek and Brown proposed a method for obtaining estimates of the strength of jointed rock masses, based upon an assessment of the interlocking of rock blocks and the conditions of the surfaces between these blocks. This method was modified over the years, and eventually, the development of a new classification called the Geological Strength Index (GSI).[4,5,6,10]

Criterion for assessment of rock mass strength using generalized Hoek-Brown as follows.

$$
\sigma_{1}=\sigma_{3}+\sigma_{c i}\left(m_{b} \frac{\sigma_{3}}{\sigma_{c i}}+s\right)^{a}
$$

Where

$\sigma_{1}$ and $\sigma_{3}$ are the maximum and minimum effective principal stresses at failure,

$m_{b}$ is the value of the Hoek-Brown constant $m$ for the rock mass,

$\mathbf{S}$ and $\mathbf{a}$ are constants which depend upon the rock mass characteristics, and

$\sigma_{\mathrm{ci}}$ is the uniaxial compressive strength of the intact rock pieces.

In order to use the Hoek-Brown criterion for estimating the strength and deformability of jointed rock masses, three parameters of the rock mass strength have to be estimated. These are namely:

1. Uniaxial compressive strength $\sigma_{\mathrm{ci}}$ of the intact rock pieces

2. Value of the Hoek-Brown constant $m_{i}$ for these intact rock pieces

3. Value of the Geological Strength Index GSI for the rock mass.

\section{Intact rock properties}

For the intact rock pieces that make up the rock mass, equation (1) simplifies to the following form:[2]

$$
\sigma_{1}=\sigma_{3}+\sigma_{c i}\left(m_{i} \frac{\sigma_{3}}{\sigma_{c i}}+1\right)^{0.5}
$$

The values of $\sigma_{\mathrm{ci}}$ are determined by laboratory tests and $\mathrm{m}_{\mathrm{i}}$ values are obtained making use of data shown in Table (1). [4, 5,10]

Journal of Engineering Sciences, Assiut University, Faculty of Engineering, Vol. 41, No. 3, May, 2013,E-mail address: jes@aun.edu.eg 
M. A. Hussein et al., Panel width affected by rock mass classifications (abu-tartur phosphate mines), pp. 1364 - 1379

\section{Table 1.}

Values of the constant $m_{i}$ for intact sedimentary rocks, by rock group. Note that values in parenthesis are estimates

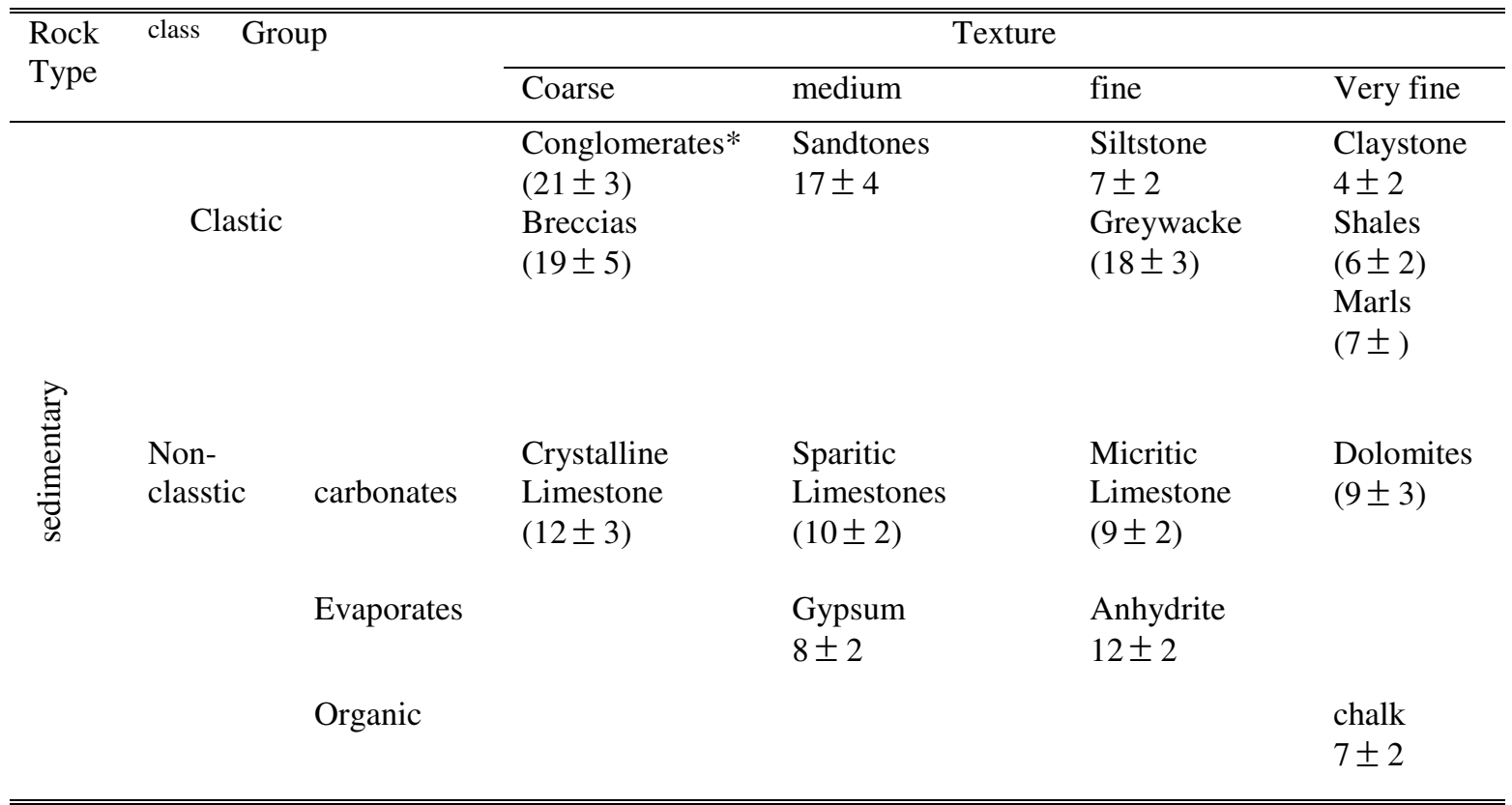

*Conglomerates and breccia may present wide range of $m_{i}$ values depending on the nature of the cementing material and the degree of cementation, so they may range from values similar to sand stone to values used for fine grained sediments.

\section{Geological strength index}

The Geological Strength Index (GSI), introduced by Hoek, Kaiser and Brown provides a number which, when combined with the intact rock properties, can be used for estimating the reduction in rock mass strength for different geological conditions. This system is presented in Table (2), for blocky rock masses [11, 12].

Experience shows that most geologists and engineering geologists are comfortable with the descriptive and largely qualitative nature of the GSI table and generally have little difficulty in arriving at an estimated value. On the other hand, many engineers feel the need for a more quantitative system in which they can "measure" some physical dimension $[5,13,14,15]$.

Journal of Engineering Sciences, Assiut University, Faculty of Engineering, Vol. 41, No. 3, May, 2013,E-mail address: jes@aun.edu.eg 
M. A. Hussein et al., Panel width affected by rock mass classifications (abu-tartur phosphate mines), pp. 1364 - 1379

\section{Table 2.}

Characterization of blocky rock masses on the basis of interlocking and joint conditions

GEOLOGICAL STRENGTH INDEX FOR
JOINTED ROCKS (Hoek and Marinos, 2000)
From the lithology, structure and surface
conditions of the discontinuities, estimate
the average value of GSI. Do not try to
be too precise. Quoting a range from 33
to 37 is more realistic than stating that
GSI = 35 . Note that the table does not
apply to structurally controlled failures.
Where weak planar structural planes are
present in an unfavourable orientation
with respect to the excavation face, these
will dominate the rock mass behaviour.
The shear strength of surfaces in rocks
that are prone to deterioration as a result
of changes in moisture content will be
reduced if water is present. When
working with rocks in the fair to very poor
categories, a shift to the right may be
made for wet conditions. Water pressure
is dealt with by effective stress analysis.

\begin{tabular}{l} 
STRUCTURE \\
\hline $\begin{array}{l}\text { INTACT OR MASSIVE - intact } \\
\text { rock specimens or massive in } \\
\text { situ rock with few widely spaced } \\
\text { discontinuities }\end{array}$ \\
\hline 112
\end{tabular}

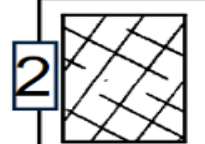

BLOCKY - well interlocked undisturbed rock mass consisting of cubical blocks formed by three intersecting discontinuity sets

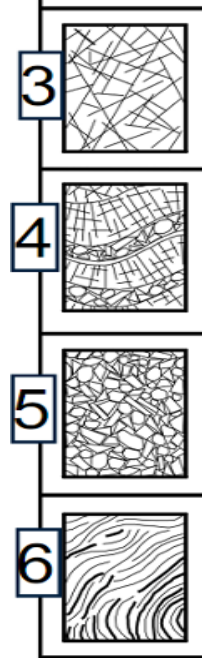

VERY BLOCKY - interlocked, partially disturbed mass with multi-faceted angular blocks formed by 4 or more joint sets

BLOCKY/DISTURBED/SEAMY - folded with angular blocks formed by many intersecting discontinuity sets. Persistence of bedding planes or schistosity

DISINTEGRATED - poorly interlocked, heavily broken rock mass with mixture of angular and rounded rock pieces

LAMINATED/SHEARED - Lack of blockiness due to close spacing of weak schistosity or shear planes

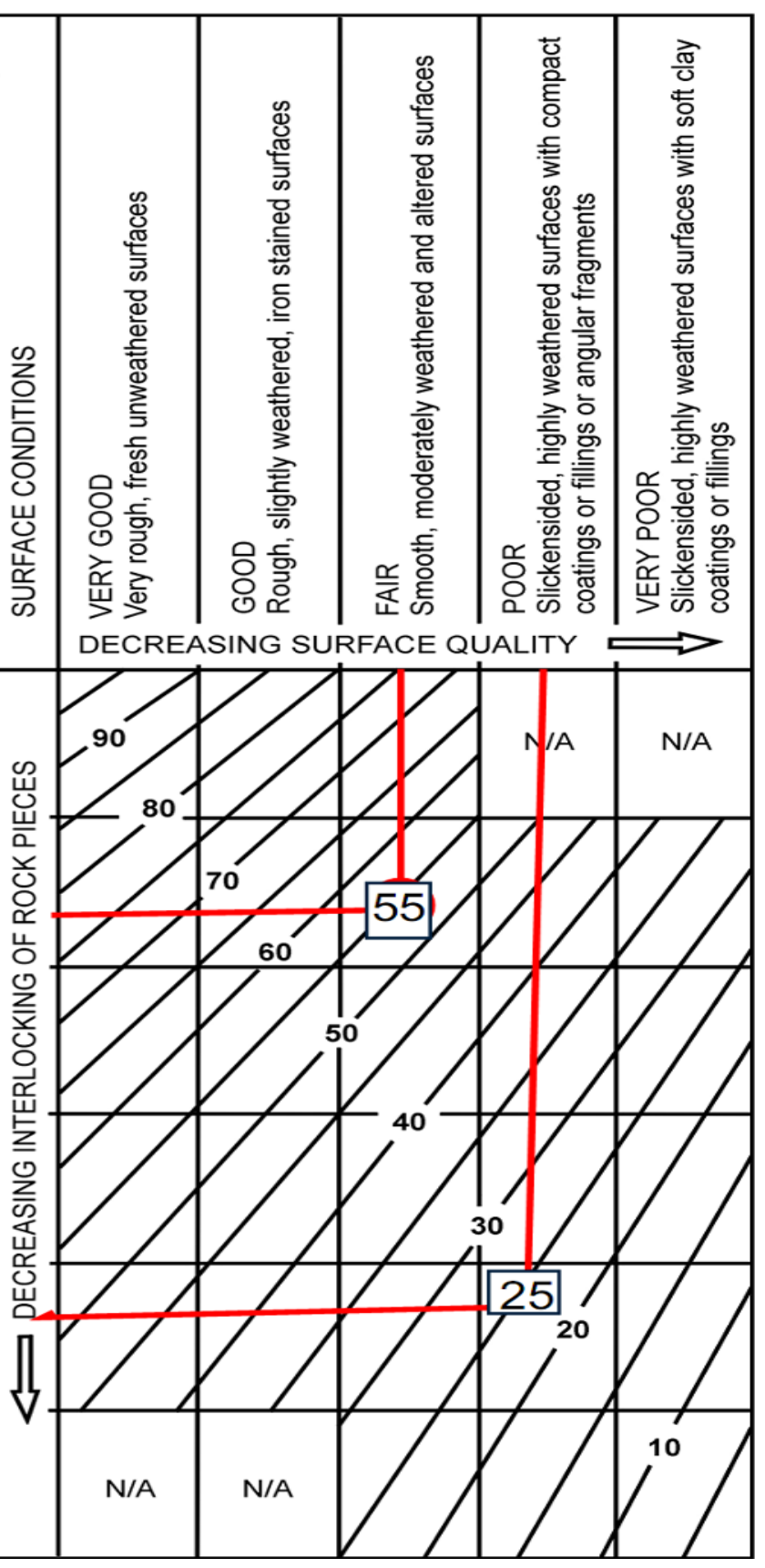

Journal of Engineering Sciences, Assiut University, Faculty of Engineering, Vol. 41, No. 3, May, 2013, E-mail address: jes@aun.edu.eg 
M. A. Hussein et al., Panel width affected by rock mass classifications (abu-tartur phosphate mines), pp. $1364-1379$

The relation between $m_{b}$ and $m_{i}$, GSI is as follows:[8,14]

$$
m_{b}=m_{i} \exp \left(\frac{G S I-100}{28}\right)
$$

The relation between $\mathrm{S}$ and GSI is as follows:[6,12]

$$
s=\exp \left(\frac{G S I-100}{9}\right)
$$

The relation between a and GSI is as follows:[6,12]

$$
a=\frac{1}{2}+\frac{1}{6}\left(e^{-G S I / 15}-e^{-20 / 3}\right)
$$

\section{Rock mass strength}

The uniaxial compressive strength of the rock mass $\sigma_{\mathrm{c}}$ is given by equation 6 . Failure initiates at the boundary of an excavation when $\sigma_{c}$ is exceeded by the stress induced on that boundary. The failure propagates from this initiation point into a biaxial stress field and it eventually stabilizes when the local strength, defined by equation 1 , is higher than the induced stresses $\sigma_{1}$ and $\sigma_{3}$. Hoek and Brown proposed this equation for estimating of rock mass strength [18].

$$
\sigma_{c m}=\sigma_{c i} \frac{\left(m_{b}+4 s-a\left(m_{b}-8 s\right)\right)\left(\frac{m_{b}}{4}+s\right)^{(a-1)}}{2(1+a)(2+a)}
$$

\section{Case study-Abu Tartur mining conditions}

The data for this case study are collected making use of the reports made by the company for the geological conditions of Abu-Tartur Plateau and properties of roof rocks and phosphate ore.

\subsection{Geological conditions of Abu-Tartur plateau}

Geological conditions of Abu-Tartur Plateau are collected from Executive Summary on Geological, Geomechanical and Geotechnical Characteristics of Abu Tartur Deposits [22].

The area is subjected to three major faults, these faults had affected on the plateau by two types of deformations mainly:

1- Ductile deformation.

These deformations have two major effects:

a - They caused folds reaching about $(2-10 \mathrm{~km}$.) which lead to erosion, inflexions and some fracture

b- They had an influence on sedimentation giving rise to lateral lithological variations.

Journal of Engineering Sciences, Assiut University, Faculty of Engineering, Vol. 41, No. 3, May, 2013,E-mail address: jes@aun.edu.eg 
M. A. Hussein et al., Panel width affected by rock mass classifications (abu-tartur phosphate mines), pp. 1364 - 1379

2- Brittle deformation.

These deformations resulting from faults, so the Russian Researchers had stressed on the importance of the following two major normal fault directions,

a - North Western trend, these faults are spaced 50 - $75 \mathrm{~m}$ apart and run 330o $-340 \mathrm{o}$, they vary in length from several hundred meters to $6-7 \mathrm{~km}$. These faults can be classified into normal faults.

b- North Eastern trend, these faults are large (active ) normal faults spaced 700 $1000 \mathrm{~m}$ and running 55o- 60o and traced along the strike for a distance of 2- $8 \mathrm{~km} \mathrm{[22]}$

From these previous geological conditions in the presence of faults and folds with poor properties of the papery shales (weak, loosing) shear zone in shale rocks is resulted, or rock is disintegrated. So the structural form for shale can be represented by the category number five in Table (2); while the interlocking between surfaces of shale rocks can be considered poor.

\subsection{The roof of the ore}

Generally, the total thickness of the overburden country rocks up to the surface of the plateau ranging from 140 to $290 \mathrm{~m}$. it may be formed by three main formations, from surface downwards, they are [22]:

i-The kurkur formation "limestone "ranges from 6 to $134 \mathrm{~m}$ thickness, ii- The Dakhla formation " shales" ranges from 100 to $135 \mathrm{~m}$, iii-The rest of Dawi formation other than ore body ranges from 20 to $40 \mathrm{~m}$.

The full characteristics of papery shale (roof rocks) can be considered as an average of all the rock types of $30 \mathrm{~m}$ thickness above the ore. Table (4), shows physical and mechanical properties of the roof rocks [22].

\section{Table 3.}

physical and mechanical properties of papery shales.

\begin{tabular}{|c|c|c|c|c|c|c|c|c|c|}
\hline \multirow{2}{*}{$\begin{array}{l}\text { Source of data } \\
\text { parameter }\end{array}$} & \multicolumn{3}{|c|}{ Russian researcher } & \multicolumn{3}{|c|}{ Consultant Sofremine } & \multicolumn{3}{|c|}{ Miscellaneous } \\
\hline & Max. & Min. & Ave. & Max. & Min. & Ave. & Max. & Min. & Ave. \\
\hline$\sigma_{c}$, Mpa. & 28.9 & 4.3 & 14 & - & & - & 19.3 & 16.2 & $17.8^{*}$ \\
\hline T, Mpa. & 4.8 & 0.4 & 2.24 & - & & 3 & 5.1 & 3.2 & $4.15^{*}$ \\
\hline$\varphi,{ }^{0}$ & 33 & 18 & 27.7 & 36 & 27 & 31.5 & 30 & 15 & $22.5^{*}$ \\
\hline$\mu$ & 0.3 & 0.3 & 0.3 & - & & - & & & \\
\hline C, Mpa. & 6.4 & 1.9 & 3.4 & - & & 0.8 & 7.7 & 5.5 & $6.6^{*}$ \\
\hline E, Gpa. & 2.8 & 0.24 & 1 & - & & 0.6 & & & $0.72 *$ \\
\hline$\gamma, \mathrm{g} / \mathrm{cm}^{3}$ & 2.41 & 1.98 & 2.14 & 2.09 & 1.52 & 1.7 & & & $1.82 *$ \\
\hline $\mathrm{W}, \%$ & --- & --- & --- & 27 & 11 & 22 & & & \\
\hline
\end{tabular}

Note: * Russian-Moscow $1973, \sigma_{c}$ uniaxial compressive strength ,T tensile strength, $\varphi$ angle of internal friction, , $\mu$ Poisson's ratio, $C$ cohesion, $\gamma$ bulk density, E modulus of elasticity, W moisture content .

Journal of Engineering Sciences, Assiut University, Faculty of Engineering, Vol. 41, No. 3, May, 2013, E-mail address: jes@aun.edu.eg 
M. A. Hussein et al., Panel width affected by rock mass classifications (abu-tartur phosphate mines), pp. $1364-1379$

\section{Estimations of rock roof properties}

Geological Strength Index GSI value is determined based on geological descriptions of Abu-Tartur area and making use of data shown in Table (2) category no. 5, so the value of GSI will equal to $25(\mathrm{GSI}=25)$

The value of mi (Hoek-Brown constant) $=6$ taken from Table (1) (clastic sedimentary rock, shales)

$$
\sigma_{c i}=14 \text { Mpa. From Table (3) }
$$

From equation (4)

$$
s=\exp \left(\frac{G S I-100}{9}\right) \quad \therefore s=\exp \left(\frac{25-100}{9}\right)=2.404 \times 10^{-4}
$$

From equation (5)

$$
\begin{aligned}
& a=\frac{1}{2}+\frac{1}{6}\left(e^{-G S I / 15}-e^{-20 / 3}\right) \\
& \therefore a=\frac{1}{2}+\frac{1}{6}\left(e^{-25 / 15}-e^{-20 / 3}\right)=531.267 \times 10^{-3}
\end{aligned}
$$

From equation (3)

$$
\begin{aligned}
m_{b} & =m_{i} \exp \left(\frac{G S I-100}{28}\right) \\
\therefore m_{b} & =6 \times \exp \left(\frac{25-100}{28}\right)=411.967 \times 10^{-3}
\end{aligned}
$$

From equation (6) of Rock mass strength

$$
\begin{gathered}
\sigma_{c m}=\sigma_{c i} \frac{\left(m_{b}+4 s-a\left(m_{b}-8 s\right)\right)\left(\frac{m_{b}}{4}+s\right)^{(a-1)}}{2(1+a)(2+a)} \\
\therefore \sigma_{c m}=14 \frac{\left(0.412+4 \times 2.404 \times 10^{-4}-0.531\left(0.412-8 \times 2.404 \times 10^{-4}\right)\right)\left(\frac{0.412}{4}+2.404 \times 10^{-4}\right)^{(0.531-1)}}{2(1+0.531)(2+0.531)} \\
\therefore \sigma_{c m}=14 \frac{195.086 \times 10^{-3} \times 2.89906}{7.75209}=1.021 \mathrm{Mpa} .
\end{gathered}
$$

Journal of Engineering Sciences, Assiut University, Faculty of Engineering, Vol. 41, No. 3, May, 2013,E-mail address: jes@aun.edu.eg 
M. A. Hussein et al., Panel width affected by rock mass classifications (abu-tartur phosphate mines), pp. 1364 - 1379

\section{The ore body (phosphate)}

The phosphate seam is not faulted and has been only subjected to folding tectonics. According to the detailed geological study above the mine, it can be said that the mine area had suffered from two types of joints.

a-The first one, is one bedding set with aperture from $1-2.5 \mathrm{~cm}$ filled with gypsum, parallel to the bedding plane

b-The second one is the three similar Structural Sets all of them having an aperture ranging from $0.2-1.0 \mathrm{~cm}$ filled with gypsum.

1. First set is $\mathrm{N} 80^{\circ}-100^{\circ}$ (direction from the north) which is parallel to the brittle direction $\mathrm{N} 80^{\circ} \mathrm{E}$ which causes well marked faults with 5 to $20 \mathrm{~m}$ throw.

2. Second set is $\mathrm{N} 120^{\circ}-140^{\circ}$ which is in parallel to the brittle direction $\mathrm{N} 120^{\circ} \mathrm{E}$ which appears discontinues in limestone causing local faults with a throw of several meters

3. The third set is, $\mathrm{N} 180^{\circ}-200^{\circ}$ which is nearly in parallel to the supple direction $\mathrm{N}$ - S which causes undulations of great amplitude about $(10 \mathrm{~km})$ marked by inflexions reaching to $3^{\circ}$ or $4^{\circ}$.

From these previous geological conditions in the presence of structural joints, blocky structure is formed by three intersecting discontinuity surfaces. So, the structural form for phosphate ore can be represented by category number two in Table (2); while the interlocking between surfaces of shale rocks is considered fair.

\subsection{Physical properties of phosphate ore}

The thickness of ore body ranges from $0.75-9.8 \mathrm{~m}$, averaging $3.5 \mathrm{~m}$, the average excavated bed thickness amounts to $3.0-3.2 \mathrm{~m}$ including the following rock types from top to bottom [22]:

1. Dolometic phosphate; ranges from 0.1 to $1.1 \mathrm{~m}$ averaging $0.4 \mathrm{~m}$.

2. Granular phosphate; ranges from 0.9 to $2.2 \mathrm{~m}$ averaging $1.5 \mathrm{~m}$

3. Black clay "intercalation" ranges form 0.15 to $0.4 \mathrm{~m}$ averaging $0.14 \mathrm{~m}$

4. Soft phosphate; ranges from 0.4 to $1.3 \mathrm{~m}$ averaging $0.9 \mathrm{~m}$

\section{Table 4.}

Physical - mechanical properties of dolomatic phosphate [22].

\begin{tabular}{|c|c|c|c|c|c|c|c|c|c|}
\hline \multirow{2}{*}{$\begin{array}{l}\text { Source of data } \\
\text { Parameter }\end{array}$} & \multicolumn{3}{|c|}{ Russian researcher } & \multicolumn{3}{|c|}{ Consultant Sofremine } & \multicolumn{3}{|c|}{ Miscellaneous } \\
\hline & Max. & Min. & Ave. & Max. & Min. & Ave. & Max. & Min. & Ave. \\
\hline$\sigma_{c}$, Mpa. & 77.1 & 14.9 & 42 & 70 & 30 & 50 & 77.3 & 20.7 & $44.7^{*}$ \\
\hline T, Mpa. & 5.5 & 1 & 3 & - & - & - & 5.58 & 3.03 & $4.19 * *$ \\
\hline$\varphi, 0$ & - & - & - & - & - & - & - & - & $39 * * *$ \\
\hline$\mu$ & 0.25 & 0.25 & 0.25 & - & - & - & - & - & - \\
\hline C, Mpa. & - & - & - & - & - & - & - & - & $11.2 * * *$ \\
\hline E, Gpa. & 13.81 & 7.65 & 10.2 & - & - & 3.8 & - & - & \\
\hline$\gamma, \mathrm{g} / \mathrm{cm}^{3}$ & 2.72 & 2.36 & 2.5 & 2.5 & 1.9 & - & - & - & $2.1 * * *$ \\
\hline
\end{tabular}

* Sofremine Alusuissc $181 \quad * *$ Assiut University 1994 *** Techmashimort-Moscow

Journal of Engineering Sciences, Assiut University, Faculty of Engineering, Vol. 41, No. 3, May, 2013, E-mail address: jes@aun.edu.eg 
M. A. Hussein et al., Panel width affected by rock mass classifications (abu-tartur phosphate mines), pp. 1364 - 1379

\section{Estimations of the ore body properties}

Geological Strength Index GSI value is determined based on geological descriptions of Abu-Tartur area and making use of data shown in Table (2) category no. 5, so the value of GSI will equal to $55(\mathrm{GSI}=55)$

The value of $\mathbf{m}_{\mathbf{i}}$ (Hoek-Brown constant) $=9$ taken from Table (1) (nonclastic sedimentary rock, nearly to Dolomites)

$\sigma_{c i}=40$ Mpa. From laboratory tests,

From equation (4)

$$
s=\exp \left(\frac{G S I-100}{9}\right) \quad \therefore s=\exp \left(\frac{55-100}{9}\right)=6.738 \times 10^{-3}
$$

From equation (5)

$$
\begin{aligned}
& a=\frac{1}{2}+\frac{1}{6}\left(e^{-G S I / 15}-e^{-20 / 3}\right) \\
& \therefore a=\frac{1}{2}+\frac{1}{6}\left(e^{-55 / 15}-e^{-20 / 3}\right)=504.048 \times 10^{-3}
\end{aligned}
$$

From equation (3)

$$
m_{b}=m_{i} \exp \left(\frac{G S I-100}{28}\right) \quad \therefore m_{b}=9 \times \exp \left(\frac{55-100}{28}\right)=1.804
$$

From equation (6) of Rock mass strength

$$
\sigma_{c m}=\sigma_{c i} \frac{\left(m_{b}+4 s-a\left(m_{b}-8 s\right)\right)\left(\frac{m_{b}}{4}+s\right)^{(a-1)}}{2(1+a)(2+a)}
$$

$\therefore \sigma_{c m}=40 \frac{\left(1.804+4 \times 6.738 \times 10^{-3}-0.504\left(1.804-8 \times 6.738 \times 10^{-3}\right)\right)\left(\frac{1.804}{4}+6.738 \times 10^{-3}\right)^{(0.504-1)}}{2(1+0.504)(2+0.504)}$

$\therefore \sigma_{c m}=40 \frac{0.94882 \times 2.0797}{5.0081}=15.760 \mathrm{Mpa}$.

\section{Calculations of panel width}

The conditions of mining are, average thickness of the bed ore $(\mathrm{h})=3.5 \mathrm{~m}$, rock mass strength $\left(\sigma_{c m}\right)$ (calculated) $=15.76 \mathrm{Mpa}$. and volumetric weight of rock $(\gamma)=25 \mathrm{kN} / \mathrm{m}^{3}$, factor of safety for square chain pillars (f.s) $=1.3$ and bord $(B)=3 \mathrm{~m}$.

Journal of Engineering Sciences, Assiut University, Faculty of Engineering, Vol. 41, No. 3, May, 2013,E-mail address: jes@aun.edu.eg 
1373

M. A. Hussein et al., Panel width affected by rock mass classifications (abu-tartur phosphate mines), pp. 1364 - 1379

\subsection{One row of chain pillars}

Take panel width $\left(\mathrm{W}_{\mathrm{L}}\right)$ to vary as $(60,90,120,150,180 \mathrm{~m})$ and width of pillar $\left(\mathrm{W}_{\mathrm{P}}\right)$ varies as $(15,20,25,30 \mathrm{~m})$ and depth of cover $(\mathrm{H})$ varies as $(100,110,120, \ldots \ldots, 200 \mathrm{~m})$. As shown in Fig (1).

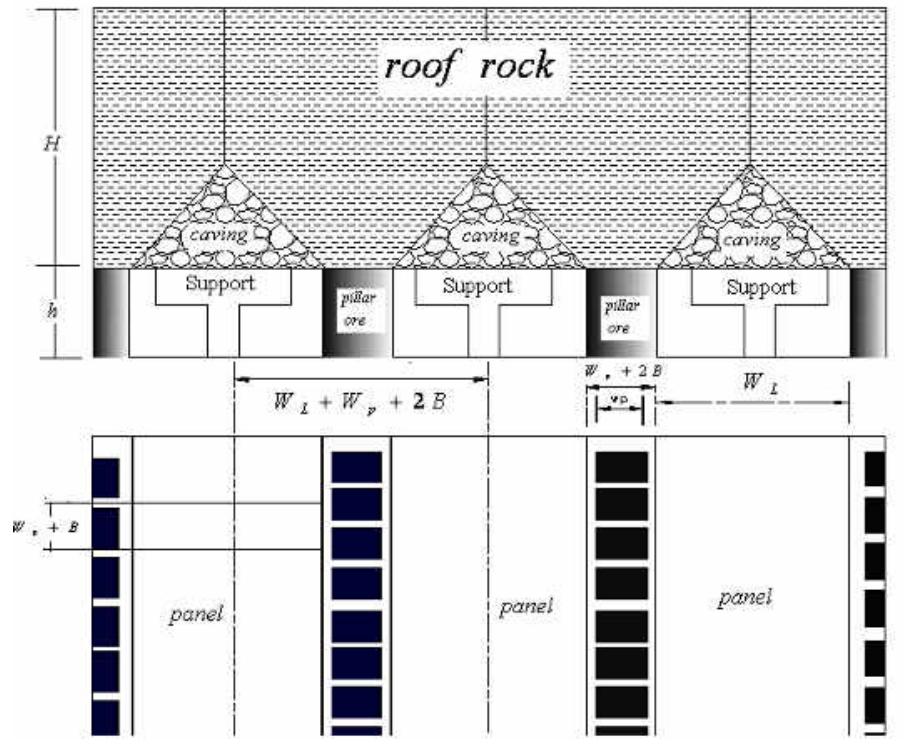

Fig. 1. Elevation and plan of the panel system and parameters.

Extraction ratio (r) is calculated by the following method [23].

$$
r=\frac{\left(W_{P}+B\right) \times\left(W_{L}+W_{P}+2 B\right)-W_{P}^{2}}{\left(W_{P}+B\right) \times\left(W_{L}+W_{P}+2 B\right)}=\frac{(30+3) *(60+30+2 * 3)-30^{2}}{(30+3) *(60+30+2 * 3)}=0.716
$$

And the losses (1-r) $=0.284$

Factor of safety

$$
\begin{aligned}
& F . S=\frac{\sigma_{c m} \times W_{P}^{0.46}}{h^{0.66}} * \frac{1-r}{\gamma^{*} H} \\
& F . S=\frac{15.76 * 30^{0.46}}{3.5^{0.66}} * \frac{0.284}{0.025^{*} 200}=1.872>1.3 \quad \text { (safe) }
\end{aligned}
$$

Table (5) shows all calculations of the factor of safety due for various panel widths, pillar widths and mining depths.

Safer conditions are summarized and represented in Table (6), which shows panel widths, pillar widths and mining depths.

Journal of Engineering Sciences, Assiut University, Faculty of Engineering, Vol. 41, No. 3, May, 2013,E-mail address: jes@aun.edu.eg 
M. A. Hussein et al., Panel width affected by rock mass classifications (abu-tartur phosphate mines), pp. 1364 - 1379

Table 5.

One row chain pillars

\begin{tabular}{|c|c|c|c|c|c|c|c|c|c|c|c|c|c|c|c|}
\hline \multirow[b]{2}{*}{$\left(\mathbf{W}_{\mathrm{P}}+\mathbf{B}\right), \mathbf{m}$} & \multirow[b]{2}{*}{$\mathbf{W}_{\mathbf{P}}, \mathbf{m}$} & \multirow[b]{2}{*}{$\mathbf{W}_{\mathrm{L}}, \mathbf{m}$} & \multirow[b]{2}{*}{$\mathbf{r}$} & \multirow[b]{2}{*}{$1-r$} & \multicolumn{11}{|c|}{ Depth of mining $(\mathrm{H}), \mathrm{m}$} \\
\hline & & & & & 200 & 190 & 180 & 170 & 160 & 150 & 140 & 130 & 120 & 110 & 100 \\
\hline \multirow{5}{*}{33} & \multirow{5}{*}{30} & & 0.716 & 0.284 & 1.873 & 1.971 & 2.081 & 2.203 & 2.341 & 2.497 & 2.675 & 2.881 & 3.121 & 3.405 & 3.745 \\
\hline & & 90 & 0.784 & 0.216 & 1.427 & 1.502 & 1.585 & 1.678 & 1.783 & 1.902 & 2.038 & 2.195 & 2.378 & 2.594 & 2.853 \\
\hline & & 120 & 0.825 & 0.175 & 1.152 & 1.213 & 1.280 & 1.356 & 1.440 & 1.536 & 1.646 & 1.773 & 1.921 & 2.095 & 2.305 \\
\hline & & 150 & 0.853 & 0.147 & 0.966 & 1.017 & 1.074 & 1.137 & 1.208 & 1.289 & 1.381 & 1.487 & 1.611 & 1.757 & 1.933 \\
\hline & & 180 & 0.874 & 0.126 & 0.832 & 0.876 & 0.925 & 0.979 & 1.040 & 1.110 & 1.189 & 1.280 & 1.387 & 1.513 & 1.664 \\
\hline \multirow{5}{*}{28} & \multirow{5}{*}{25} & 60 & 0.755 & 0.245 & 1.487 & 1.565 & 1.652 & 1.749 & 1.858 & 1.982 & 2.124 & 2.287 & 2.478 & 2.703 & 2.973 \\
\hline & & 90 & 0.816 & 0.184 & 1.118 & 1.177 & 1.242 & 1.315 & 1.398 & 1.491 & 1.597 & 1.720 & 1.864 & 2.033 & 2.236 \\
\hline & & 120 & 0.852 & 0.148 & 0.896 & 0.943 & 0.996 & 1.054 & 1.120 & 1.195 & 1.280 & 1.378 & 1.493 & 1.629 & 1.792 \\
\hline & & 150 & 0.877 & 0.123 & 0.747 & 0.787 & 0.831 & 0.879 & 0.934 & 0.997 & 1.068 & 1.150 & 1.246 & 1.359 & 1.495 \\
\hline & & 180 & 0.894 & 0.106 & 0.641 & 0.675 & 0.712 & 0.754 & 0.801 & 0.855 & 0.916 & 0.986 & 1.069 & 1.166 & 1.282 \\
\hline \multirow{5}{*}{23} & \multirow{5}{*}{20} & 60 & 0.798 & 0.202 & 1.106 & 1.164 & 1.229 & 1.301 & 1.383 & 1.475 & 1.580 & 1.702 & 1.844 & $\underline{2.011}$ & 2.212 \\
\hline & & 90 & 0.850 & 0.150 & 0.820 & 0.863 & 0.911 & 0.965 & 1.025 & 1.093 & 1.172 & 1.262 & 1.367 & 1.491 & 1.640 \\
\hline & & 120 & 0.881 & 0.119 & 0.652 & 0.686 & 0.724 & 0.767 & 0.814 & 0.869 & 0.931 & 1.002 & 1.086 & 1.185 & 1.303 \\
\hline & & 150 & 0.901 & 0.099 & 0.540 & 0.569 & 0.601 & 0.636 & 0.676 & 0.721 & 0.772 & 0.832 & 0.901 & 0.983 & 1.081 \\
\hline & & 180 & 0.916 & 0.084 & 0.462 & 0.486 & 0.513 & 0.543 & 0.577 & 0.616 & 0.660 & 0.710 & 0.770 & 0.840 & 0.924 \\
\hline \multirow{5}{*}{18} & \multirow{5}{*}{15} & & 0.846 & 0.154 & 0.739 & 0.778 & 0.822 & 0.870 & 0.924 & 0.986 & 1.056 & 1.138 & 1.232 & 1.345 & 1.479 \\
\hline & & 90 & 0.887 & 0.113 & 0.540 & 0.568 & 0.600 & 0.635 & 0.675 & 0.719 & 0.771 & 0.830 & 0.899 & $\overline{0.981}$ & 1.079 \\
\hline & & 120 & 0.911 & 0.089 & 0.425 & 0.447 & 0.472 & 0.500 & 0.531 & 0.566 & 0.607 & 0.654 & 0.708 & 0.772 & 0.850 \\
\hline & & 150 & 0.927 & 0.073 & 0.350 & 0.369 & 0.389 & 0.412 & 0.438 & 0.467 & 0.500 & 0.539 & 0.584 & 0.637 & 0.701 \\
\hline & & 180 & 0.938 & 0.062 & 0.298 & 0.314 & 0.331 & 0.351 & 0.373 & 0.397 & 0.426 & 0.458 & 0.497 & 0.542 & 0.596 \\
\hline \multirow{5}{*}{13} & \multirow{5}{*}{10} & & 0.899 & 0.101 & 0.402 & 0.424 & 0.447 & 0.474 & 0.503 & 0.537 & 0.575 & 0.619 & 0.671 & 0.732 & 0.805 \\
\hline & & 90 & 0.927 & 0.073 & 0.289 & 0.304 & 0.321 & 0.339 & 0.361 & 0.385 & 0.412 & 0.444 & 0.481 & 0.525 & 0.577 \\
\hline & & 120 & 0.943 & 0.057 & 0.225 & 0.237 & 0.250 & 0.265 & 0.281 & 0.300 & 0.321 & 0.346 & 0.375 & 0.409 & 0.450 \\
\hline & & 150 & 0.954 & 0.046 & 0.184 & 0.194 & 0.205 & 0.217 & 0.230 & 0.246 & 0.263 & 0.283 & 0.307 & 0.335 & 0.369 \\
\hline & & 180 & 0.961 & 0.039 & 0.156 & 0.164 & 0.173 & 0.184 & 0.195 & 0.208 & 0.223 & 0.240 & 0.260 & 0.284 & 0.312 \\
\hline
\end{tabular}

Underlined values are the factor of safety calculated (safer conditions $\geq 1.3$ )

Journal of Engineering Sciences, Assiut University, Faculty of Engineering, Vol. 41, No. 3, May, 2013, E-mail address: jes@aun.edu.eg 
1375

M. A. Hussein et al., Panel width affected by rock mass classifications (abu-tartur phosphate mines), pp. 1364 - 1379

\section{Table 6.}

Summarized panel widths, pillar widths and mining depths at safe conditions.

\begin{tabular}{|c|c|c|c|c|c|c|c|}
\hline \multicolumn{2}{|c|}{$\left(\mathrm{W}_{\mathrm{P}}\right)=15 \mathrm{~m}$} & \multicolumn{2}{|c|}{$\left(\mathrm{W}_{\mathrm{P}}\right)=20 \mathrm{~m}$} & \multicolumn{2}{|c|}{$\left(W_{P}\right)=25 \mathrm{~m}$} & \multicolumn{2}{|c|}{$\left(\mathrm{W}_{\mathrm{P}}\right)=30 \mathrm{~m}$} \\
\hline (H), m & $\left(\mathrm{W}_{\mathrm{L}}\right), \mathrm{m}$ & $(\mathrm{H}), \mathrm{m}$ & $\left(\mathrm{W}_{\mathrm{L}}\right), \mathrm{m}$ & $(\mathrm{H}), \mathrm{m}$ & $\left(\mathrm{W}_{\mathrm{L}}\right), \mathrm{m}$ & $(\mathrm{H}), \mathrm{m}$ & $\left(\mathrm{W}_{\mathrm{L}}\right), \mathrm{m}$ \\
\hline 100 & 71 & 100 & 120 & 100 & 177 & 130 & 177 \\
\hline 110 & 62 & 110 & 107 & 110 & 158 & 140 & 162 \\
\hline & & 120 & 96 & 120 & 142 & 150 & 148 \\
\hline & & 130 & 87 & 130 & 130 & 160 & 137 \\
\hline & & 140 & 79 & 140 & 118 & 170 & 127 \\
\hline & & 150 & 72 & 150 & 108 & 180 & 118 \\
\hline & & 160 & 65 & 160 & 99 & 190 & 110 \\
\hline & & 170 & 60 & 170 & 91 & 200 & 102 \\
\hline & & & & 180 & 85 & & \\
\hline & & & & 190 & 79 & & \\
\hline & & & & 200 & 73 & & \\
\hline
\end{tabular}

From the results shown in Table (6), we see that with the increase of mining depth, the panel width will be decreased at a constant pillar width; while the panel width will be increased with increasing pillars widths at a constant mining depth as shown in Fig (2); while Fig. (3), shows relation between the extraction ratio and panel width at different pillar widths.

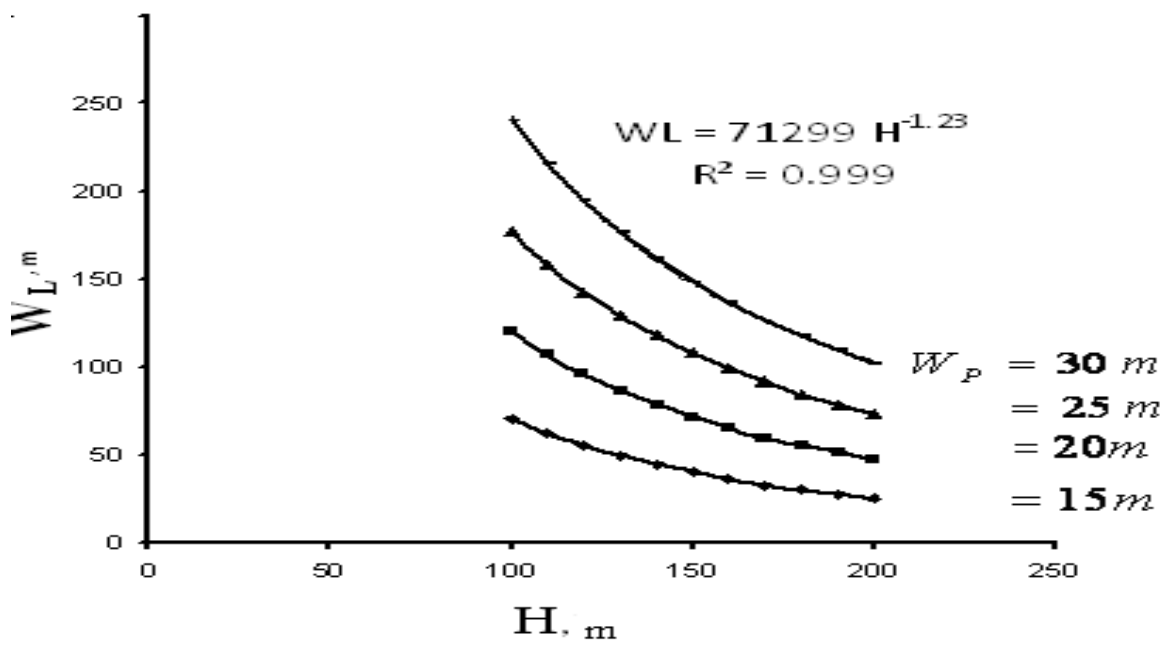

Fig. 2. The relation between width of panel and mining depths for different pillar widths.

Journal of Engineering Sciences, Assiut University, Faculty of Engineering, Vol. 41, No. 3, May, 2013,E-mail address: jes@aun.edu.eg 
M. A. Hussein et al., Panel width affected by rock mass classifications (abu-tartur phosphate mines), pp. $1364-1379$

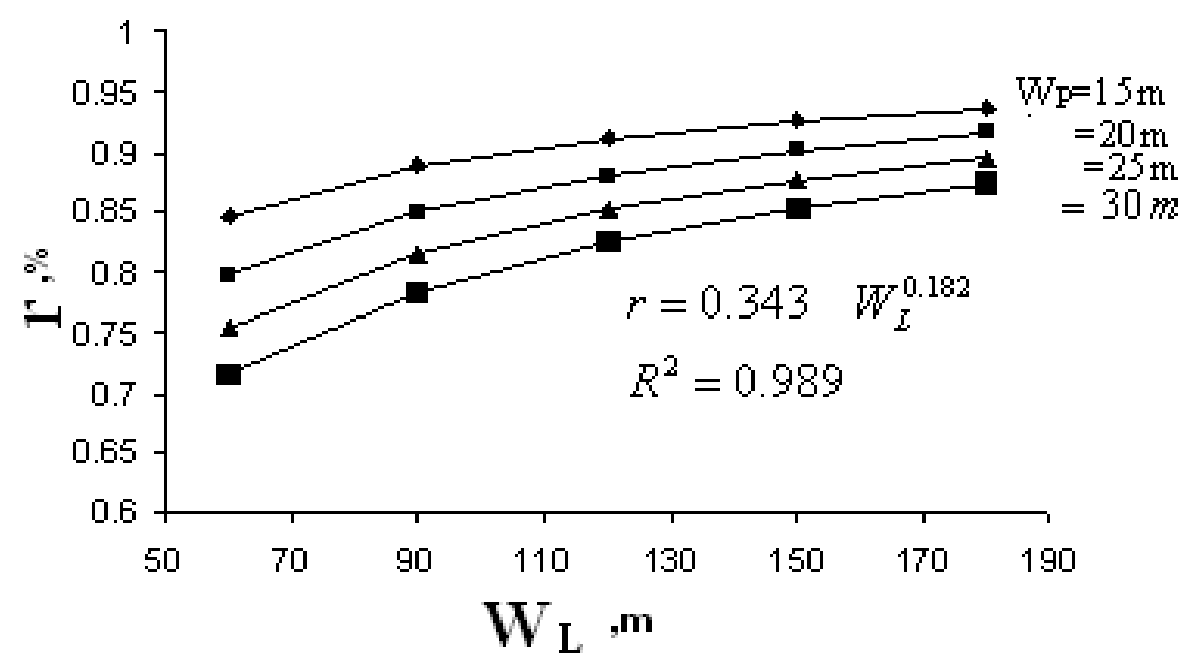

Fig. 3. The relation between extraction ratio and panel width for different pillar widths.

For the conditions of Abu-Tartur the depth of mining varies from 140 to $290 \mathrm{~m}$ with an average of $200 \mathrm{~m}$ therefore, the optimum panel width is $102 \mathrm{~m}$ and pillar width $30 \mathrm{~m}$ with extraction ratio $=80 \%$ as shown in Table (7)

\section{Table 7.}

Extraction ratio at different pillar widths and panel widths.

\begin{tabular}{cccc}
\hline \hline Pillar width & Panel width & Extraction ratio & Comment \\
\hline 15 & 25 & 0.73 & Very short longwall*, small extraction ratio $^{*}$ \\
20 & 47 & 0.76 & short longwall, fair extraction ratio \\
25 & 73 & 0.79 & longwall, small panel width \\
30 & 102 & 0.80 & Optimum panel width \\
\hline \hline
\end{tabular}

* Short wall mining length (45-60) $\mathrm{m}$. [23]

\subsection{Panel width from the ventilation point of view}

This checking is to be done to satisfy the requirements of the mining regulations which prescribe the maximum velocity and minimum quantity of air to be passed thorough face. Panel width can be calculated by ventilation as follows:. [3]

$$
W_{L V}=\frac{60 V \cdot b \cdot m_{e} \cdot \psi}{i \cdot r_{1} \cdot q_{a} \cdot \gamma \cdot m_{p} \cdot c \cdot \delta}, \quad \text { meters }
$$

Where:

$\mathbf{W}_{\mathbf{L V}}$ is panel width by ventilation, $\mathbf{V}$ is maximum air velocity $=4 \mathrm{~m} / \mathrm{s}, \mathbf{b}$ is minimum width of working place in productive face $=2.5 \mathrm{~m}, \mathrm{~m}_{\mathrm{e}}$ is the extracted thickness ore bed

Journal of Engineering Sciences, Assiut University, Faculty of Engineering, Vol. 41, No. 3, May, 2013,E-mail address: jes@aun.edu.eg 
M. A. Hussein et al., Panel width affected by rock mass classifications (abu-tartur phosphate mines), pp. 1364 - 1379

$=3.5 \mathrm{~m}, \psi$ is the coefficient accounting for the narrowing of the cross-section of the airway $=0.95$ for steel face support, $\mathbf{i}$ is the number of productive cycle $=1, \mathbf{r}_{1}$ is the depth of cut $1.6 \mathrm{~m}, \mathbf{q}_{\mathbf{a}}$ is the quantity of air $\mathrm{m}^{3} / \mathrm{min}$. per ton of daily production of the face depending on gas emission, no gas emission in our case assume first category (very small gas emission) therefore $\mathbf{q}_{\mathbf{a}}=1 \mathrm{~m}^{3} /$ min.per ton of daily productive, $\gamma$ is the average volume weight for phosphate ore $=2.5 \mathrm{t} / \mathrm{m}^{3}, \mathbf{m}_{\mathbf{p}}=$ productive thickness of ore bed $=3.5 \mathrm{~m}, \mathbf{c}$ is the coefficient of ore recovery $=0.80$ and $\boldsymbol{\delta}$ is the coefficient accounting for the fact some quantity of the air will leak into goaf assume all air goes to face $=1$.

$$
W_{L V}=\frac{60 \times 4 \times 2.5 \times 3.5 \times 0.95}{1 \times 1.6 \times 1 \times 2.5 \times 3.5 \times 0.80 \times 1}=178 \mathrm{~m}
$$

So, the ventilation requirement does not limit the width of panel and can take safely panel width equal to $102 \mathrm{~m}$ (100 approximately).

The effect of panel width (longwall face length) on strata control is uncertain. Investigations in Great Britain have shown that longer face do not experience more roof failure than shorter ones, and mining research in west found that, in strong roof strata, caving was improved in longer faces. [24]

No relationship between optimum panel width and strata control has been developed.

Therefore, selection of the panel width is guided largely by economic consideration. Cost of equipment ownership increase with panel width increase [25].

\section{Conclusions}

From this study, the following conclusions can be drawn:

1) From the mechanical properties of roof rocks (papery shales) and phosphate ores with applying GSI system, the value of $\sigma_{c m}$ is as follows :

1-1-for roof rocks, $\sigma_{c m}=1.021 M P a$.

a) for phosphate ore are $\sigma_{c m}=15.760 \mathrm{Mpa}$.

2) The relation between panel width and depth of mining can be expressed for $\mathrm{Abu}$ Tartur mines conditions by this equation $w_{L}=71299 H^{-1.23}$ at pillar width is $30 \mathrm{~m}$.

3) The relation between extraction ratio and panel width can be expressed by this equation $r=0.343 W_{L}^{0.182}$ when pillar width equals to $30 \mathrm{~m}$.

4) The panel width by ventilation is calculated to be $178 \mathrm{~m}$ : so, ventilation requirements do not limit the panel width (102m)

5) No relationship between optimum panel width and strata control has been developed. Therefore, selection of the panel width is guided largely by economic consideration. Cost of equipment ownership increase with panel width increase.

Journal of Engineering Sciences, Assiut University, Faculty of Engineering, Vol. 41, No. 3, May, 
M. A. Hussein et al., Panel width affected by rock mass classifications (abu-tartur phosphate mines), pp. 1364 - 1379

6) The optimum panel width for the condition of Abu-Tarur phosphate mine is $102 \mathrm{~m}$ with an extraction ratio $=80 \%$ when pillar width $=30 \mathrm{~m}$ as show in Table (7), while the panel width (wall length) applied in Abu Tartur mines area is $150 \mathrm{~m}$. The recommended value (102) varies differently from the applied longwall length. So we recommend the application of panel width to be about $100 \mathrm{~m}$ to secure safe mining conditions and the probability of roof falls may be decreased which is the major problem facing underground mining in this area.

\section{References}

[1] Chapter6 Rock mass properties and classifications, Imrwww.epfl.ch/../Rock../ENS_080312_EN_JZ_N...

[2] Swart, A.H. Investigation of factors governing the stability of stope panels in hard rock mines in order to define a suitable design methodology for shallow mining operations. A thesis submitted to Faculty of Engineering, Built Environment and Information Technology of the University of Pretoria, in partial fulfillment of the requirements for the degree of Master of Mining Engineering, 2005.

[3] Vorobjev, B.M., Deshmukh,R.T. Advanced of coal mining. Vol.one, ch6:109-134p, Asia Publishing House, London, 1966

[4] Hoek, E. and Brown, E.T. Practical estimates of rock mass strength. Int. J. Rock Mech. Min. Sci. Vol. 34, No. 8, pp 1165-1186, 1995.

[5] Hoek, E., Carranza, C. and Corkum, B. HOEK-BROWN FAILURE CRITERION. Consulting Engineer, Vancouver, Canada, Itasca Consulting Group Inc., Minneapolis, USA,Rocscience Inc., Toronto, Canada, 2002.

[6] Bieniawski, ZT. Engineering classification of rock masses. Trans S. African Inst. Civ. Engrs. 15(12):335-44, 1973.

[7] Galving, J. Strength of irregular and rectangular shaped pillars. University of New South Wales, Project C5024, 1995.

[8] Hudyma, M.R. Rib pillar design in open stope mining. Master thesis, University of British Columbia.

[9] Krauland, N. and Soder P. Determining pillar strength from pillar failure observations. E\&MJ PP(34-40), 1987.

[10] Potvin, Y. Carter, J., Dyskin, A. and Jeffrey R. Estimating the Mechanical Properties of Rock Masses. Australian Centre for Geomechanics, Perth, ISBN 978-09804185-5-2, 2008.

[11] Hoek, E. Reliability of Hoek-Brown estimates of rock mass properties and their impact on design. Int. J. Rock Mech. Min. Sci. Vol. 35, No. 1, pp 63-68, 1998.

[12] David, C. Numerical validation and refinement of empirical rock mass modulus estimation. A thesis submitted to the Department of Geological Sciences \& Geological Engineering In conformity with the requirements for the degree of Master of Science Queen's University Kingston, Ontario, Canada September, 2011.

[13] Van, P. and Vasarhelyi, B. Sensitivity analysis of the Hoek- Diederichs rock mass deformation modulus estimating formula. Dept. Engng. Mat. \& Ening. Geol., Budapest University of Technology and Economics, Budapest, Hungary

[14] Hoek, E., Marinos, P. and Benissi, M. Applicability of the Geological Strength Index (GSI) classification for very weak and sheared rock masses. The case of the Athens Schist Formation. Bull. Engng. Geol. Env. 57(2), 151-160, 1998.

[15] Barton, R., Lien, R. and Lunde, J. Engineering classification of rock masses for the design of tunnel support. Rock Mech. 6(4):189-239, 1974.

Journal of Engineering Sciences, Assiut University, Faculty of Engineering, Vol. 41, No. 3, May, 
M. A. Hussein et al., Panel width affected by rock mass classifications (abu-tartur phosphate mines), pp. 1364 - 1379

[16] Marino, V., Marino P. and Hoek, E. The geological strength index applications and limitations. Bull Eng. Geol. Environ, DOI 10.1007/s10064-004-0270-5, 64:55-65, 2005.

[17] Hoek, E. and Marino, P. A brief history of the development of the Hoek-Brown failure criterion. November 2006.

[18] Siambaos, G.T and Saroglou ,H. Excavatability assessment of rock masses using the Geological Strength Index (GSI) .Bull Eng Geol Environ DOI10.1007/s10064009-0235-9, 69:13-27, 2010.

[19] Hoek, E. and Diederichs, M.S. Empirical estimation of rock mass modulus. International Journal of Rock Mechanics \& Mining Sciences 43 (2006)203-215 Accepted 9 June 2005 Available online 15 August 2005

[20] Bieniawski Z. T. Engineering classification of jointed rock masses .Trans S Afr Inst Civ Eng 15:335-344, 1973.

[21] Hoek, E. and Guevara, R. Over coming Squeezing in the Yacambu - Quibor Tunnel,Venezuela. Rock Mech., Rock Engng. DOI 10.1007/s00603-009 0175-5, 42:389-418, Printed in The Netherlands Received December 5 2008; Accepted February 11 2009; Published online Aprill 72009 Springer-Verlag 2009.

[22] Executive Summary on Geological, Geomechanical and Geotechnical Characteristics of Abu Tartur Deposits. Geological and Mining research department Abu Tartur Phosphate project, July 1997.

[23] Hhoward, L. Hattman. Introductory Mininig Eng.. Johan Wiley \&Sons,pp440 ,1987.

[24] Ernest, A. Curth. Design of longwall mining system. 165- 207 ,proceeding first conference on ground control problems in Illinois coal Basin, Editors Yoginder P.C and A. Van Besien, southern Illinois university at Carbondale, June,1980.

[25] Holand, C.T. Notes of the theory of maximum pressure arch and yield pillar techniques as applied to entry panel design. Proceding of coal mining institute of America, Pittrs Burgh, 14P, Dec.1962.

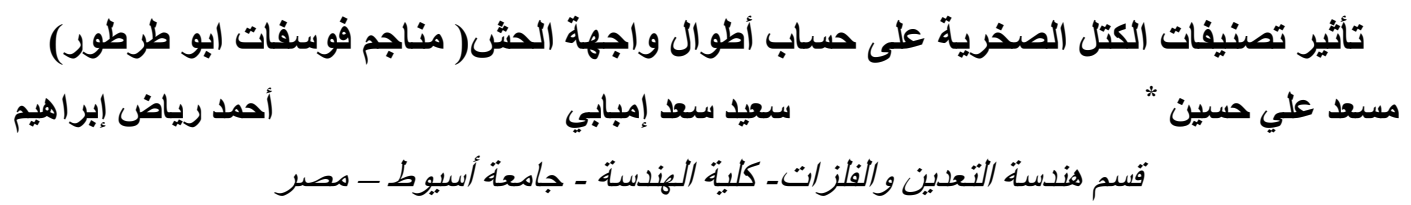



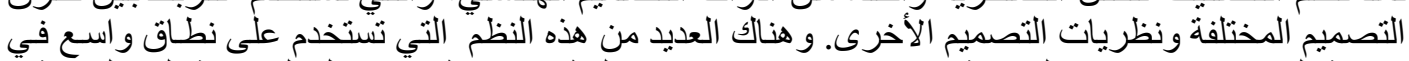

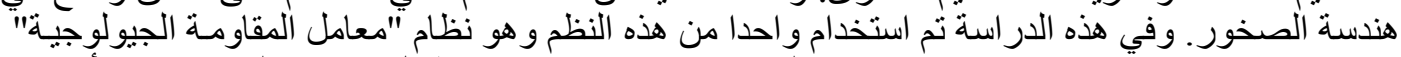
Geological Strength Index(GSI)



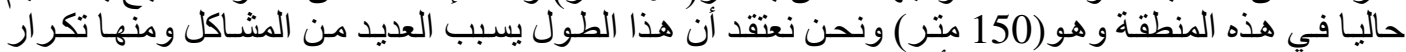

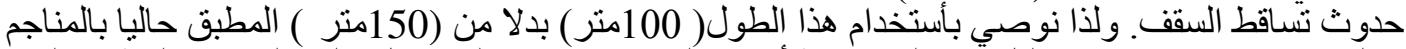

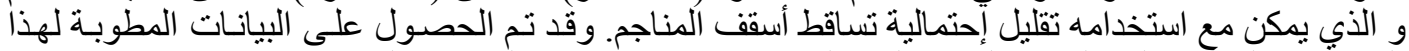



Journal of Engineering Sciences, Assiut University, Faculty of Engineering, Vol. 41, No. 3, May, 2013, E-mail address: jes@aun.edu.eg 